\title{
Orchid Conservation Initiatives in Malaysia
}

\author{
Rusea Go ${ }^{1 *}$, Edward Entalai Besi ${ }^{1}$, Mohd Puat Dahalan $^{2}$, Rafae Ahmad ${ }^{2}$, Ag. Shaffie Ag. \\ Ahmadni $^{3}$ and Runi Sylvester Pungga ${ }^{4^{*}}$ \\ ${ }^{1}$ Biology Department, Faculty of Science, Universiti Putra Malaysia, 43400 UPM \\ SERDANG, Selangor Darul Ehsan, Malaysia
}

${ }^{2}$ Selangor State Forestry Department, $3{ }^{\text {rd }}$ Floor, Sultan Salauddin Abdul Aziz Shah Building, 40660 Shah Alam, Selangor Darul Ehsan, Malaysia

${ }^{3}$ Jabatan Perhutanan Negeri Perlis, KM2, Jalan Kaki Bukit, 01000 Kangar, Perlis

${ }^{4}$ Forest Department Sarawak, Bangunan Wisma Sumber Alam, Jalan Stadium, Petra Jaya 93660, Kuching, Sarawak, Malaysia

*Corresponding Authors email: rusea@upm.edu.my; runisp@sarawak.gov.my

\begin{abstract}
Orchids totalling close to 4000 species in Malaysia are one of the most diverse and most widespread family here had gained momentum in recognition among policy makers and guardians of the forest as one of the profiles that fit and can benefit plant conservation on a broad scale in recent years. Listed not only as conservation indicator but also as priority germplasm for sustainable floriculture industry in the country, a milestone that could safeguard wild orchids from verge of extinction in the natural habitat. Through our 30 years of studying orchids in the wild, we understand more about the distribution, rarity, threats and extinction of orchids than ever before, and we have the scientific tools to address many of the problems, yet many species face daily threats including habitat loss and unsustainable exploitation mainly via Internet trade. Prior to executing workable conservation plan, various research institutions working closely with Forestry Departments in Malaysia to first inventory and document the orchid species richness in the country. Selangor, Sarawak and Perlis Forestry Departments in collaboration with UPM have published seven orchid books that cover various habitat types. Selangor Forestry Department is leading on publishing biodiversity data in form of books for its various ecotourism's sites and State Parks, and had published two books on orchids. Sarawak state has published one on the limestone orchids, and Perlis is the first to embark on the feat published one in 2010 and currently preparing a new book that includes other flagship wild flowers. Realizing the importance of documenting its biodiversity wealth, Malaysia has developed an information system that would be a one-stop retrieval point or repository for biodiversity facts and as a part of the commitments to CBD to facilitate reporting and the transfer of biological diversity and conservation-related information both nationally and internationally.
\end{abstract}

Keywords: orchid books, database, species, documentations, policy, extinction

\section{INTRODUCTION}

Though large population of orchid is still confined in their natural habitat, in many parts of the world their number is decreasing due to their high demand and population pressure. Many 
orchid species are threatened due to their habitat destruction and indiscriminate collection. At present, the orchids also figure prominently in the IUCN Red List (Red Data Book prepared by International Union for Conservation of Nature) and the family is now included in Appendix II of Convention on International Trade in Endangered Species of Wild Fauna and Flora (CITES), where the international trade is strictly controlled and monitored. Our world is losing plant species faster than ever prior to the history of geologic without any doubt. Due to the urgent needs and requirements of land for more agricultural, housing and industrial developments, roads and energy sources, the plant communities of many regions are altering dramatically. There are few factors, which also cause the orchids become threatened and disappearing, worst still extinct.

The three major treats are logging that leads to destruction of habitat, land clearance for the usage of agriculture, traditional farming and infrastructure development, and illegal collections of valuable orchids such as Paphiopedilum, Phalaenopsis, Anoethochilus, Vanda, Bulbophyllum, Dendrobium, and Gramatophyllum have resulted in their drastic disappearing in the wild. Logging is indeed a very destructive factor. Annual rates of logging range are from 760 sq. $\mathrm{km}$ to 900 sq. $\mathrm{km}$ in Peninsular Malaysia (Davis et al. 1986). The adverse effects of opening up of the canopy, erosion and silting of streams directly affect the survival of the shade-loving plants of the ground layer (Kiew, 1991). Besides that, the ecosystem balances also being affected such as the changing of microclimate and the micro temperature of the orchid habitat. Wild orchids are quiet sensitive to the changes in the environment, especially the mycoheterotrophs orchid like Stereosandra javanica and jewels orchid like Anoectochilus species and Macodes petola. Large scale of land clearing, deforestation and fire burning in the forest has indirectly destroyed the natural habitat of the wild orchids. Agriculture activities also affect the survival of the epiphytes and terrestrial orchids. Clearing land for new farms is common in developing tropical countries (AOS, 1983).

While most orchidologist bemoan the loss of habitat and species, there is not enough actions being undertaken on the ground to cease the loss of orchid biodiversity, and any efforts helping to undo the trend must be highlighted and supported politically, technically, and financially (IUCN/SSC Orchid Specialist Group, 1996). Therefore, we have aimed to apply the developed guideline and criteria published by IUCN Species Survival Commission (IUCN/SSC) group. Universiti Putra Malaysia (UPM) has a long history of collaboration research with other government agencies, universities and private sectors within and outside the country prior to implementing effective conservation plans for orchids. The aimed is to first inventory and document the orchid species richness in the country. Selangor, Sarawak and Perlis Forestry Departments in collaboration with UPM have published seven orchid books that cover various habitat types. The books synthesize all available published materials and information about orchids.

Malaysia's Ministry of Water, Land and Natural Resources (KATS) in collaboration with various agencies including UPM has developed MyBIS, an information system that would be a one-stop retrieval point or repository for biodiversity facts and as a part of the commitments to Convention on Biological Diversity (CBD) to collate information related to Malaysia's biodiversity and conservation-related information both nationally and internationally.

DNA barcoding of plants has been a major approach to supplement identification of species and the authors have been a member to the consortium since 2009. The DNA barcoding has been proposed as a simple yet effective means by which identification of the individual species can be done accurately. Each barcode is unique to each species and gives clear-cut 
identification even between closely related species (Chase \& Fay, 2009). The applications of DNA barcoding now have far reaching effects and has been demonstrated to be extremely useful in many cases. Sønstebø et al. (2010) reconstructed past vegetation in the Arctic using data obtained through DNA barcoding. Studies that focus on regulation and control of food are able to employ barcoding methods to screen unwanted adulterants in herbal remedies usually included in by unscrupulous manufacturers (Selvaraj et al., 2012; Techen et al., 2014). In fish sales, retailers and restaurants often deceptively mislabel fish names in order to sell those fishes at a higher price that it actually is. Through DNA barcoding, Wong et al. (2008) discovered that $25 \%$ of seafood in North America is potentially mislabelled highlighting the greater utility of DNA barcoding in law enforcement especially with food and safety regulations.

\section{METHODOLOGY}

This case report is another objective of a conservation effort carried by UPM's Botany and Conservation team in collaboration with the Malaysia's Forestry Departments as an attempt to fill in this gap in examining the combinations of direct and underlying agents and causes of the habitat losses and extinctions of the orchid community in Malaysia, and to support the global conservation efforts carried by IUCN/SSC Orchid Specialist Group by analysing the problems and develop solutions to the crisis. The collective information used in this study have been based on four main sources of information: (i) review of existing literatures and documents; (ii) fieldworks in accessible disturbed forests in Peninsular Malaysia and Borneo; (iii) personal and professional experiences, including expert consultations; and (iv) interviews and discussions with the both professional and non-professional relevant individuals and groups from in Peninsular Malaysia. This case study report has three important parts: Part One highlights the major direct and underlying driver causes of forest degradation and orchid extinction in Malaysia region; Part Two gives the overview on the effects of forest destruction caused by anthropogenic activities, illegal orchid collection and smuggling on the orchid community and their current conservation status in Malaysia; and Part Three explores the keys elements for conservation planning and the general recommendations for future safeguarding actions in Malaysia.

\section{RESULTS AND DISCUSSIONS}

\section{PART ONE}

\section{Forest Degradation and Habitat Alteration Drivers in Malaysia}

\section{Direct Causes}

The major culprit responsible for the massive forest destruction in the Malaysia region which has eventually led to the habitat and ecology disruptions to the orchid community is observed to be the industrial logging activities, mainly for timber extraction (Figure 1). Empirically, these activities were carried by both legal and illegal actions, and by comparison, the executions of the 'legal' logging activities are in the permanent forest reserves (PFRs) or Hutan Simpan Kekal (HSK). PFRs are any forest and non-forest area established for forestry purposes under section 7, 8 and 9 of the National Forestry Act 1984 (Amended 1993). The PFRs are classified into two categories, specifically (i) of forest production and (ii) forest protection. The adoption of the terms, 'permanent forest reserve for production' and 'permanent forest reserve for protection' given rise to many misconceptions, especially in Malaysia (Malaysia Academy 
of Science, 2014). The 'permanent reserve forest for production' implies an area of forest gazetted by the law and being kept until the time it can be intensely logged, until to the stage it will be useless for further timber production and which is then supposedly to be regenerated, or otherwise alienated (National Forestry Act 1984; 2018, January). A large part of the forest cover in Malaysia has been classified as the reserved forest for timber resources (Abdul Rahman, 2012). Production of timber or lumber is the main source of outcome for the states. The forest destructions by logging become more serious due to the illegal logging in both reserved forest and other government forest land, violated the laws and regulations set by the government authorities, as observed.

The issues have become more serious, nowadays, getting uncontrolled, and also have reached to the terms where the legislations, regulations and policies enforced seem to be 'less stringent' at the same time as the human actions grow to be 'less considerate'. This is true due to various factors such as presence of increasing demand for logs, mainly the tropical hardwoods, and other primary forest products from within and outside the country, and land clearing for oil palm plantation areas, mining and large dam projects (Abdul Rahman, 2012). In 2011, Malaysia had lower total forest area of totally protected forests if were to compare with the total forest area for timber production (Abdul Rahman, 2012; Malaysia Academy of Science, 2014). The large PFRs area allocated for timber production provides an opportunity for loggers and developers companions to harvest large profits at the expense of the environment. Recently, based on the current study, the forest logging in the nature reserved forest has spread to the surrounding area near the National Parks area. Therefore, an urgent demand for more permanent forest reserves gazetted for protection where logging must be terminated immediately.

\section{Indirect Causes}

The one indirect driver that has been restricting the conservation efforts planned from being fully effectual is the continued contradictions arising from different levels of federal and state authorities and jurisdictions on the legislation and policies related to the protection of their land and forest resources, which are generally differ regionally within the states in the country. They divert extra attention towards the generation of state's income and economy growth instead of safeguarding the well-being of the forest community being exposed to the environmental disturbance triggered by the forest clear cutting activities (BERNAMA, 2015, March 5; SINAR, 2017, September 18). Also, other than the timber extraction for commercialization, the development choices made by both federal and state governments have preferred large scale projects, including the commercial agriculture plantations and massive dam projects (Lye, 2000, 2005; Hairul et al., 2016). The monitoring and enforcement of the many laws for land and forest protection are relatively less effective. Revisions on the forestry-related acts aimed to mark a better control on the destructive effect of forest exploitation; however, it seems inadequate. The efforts have not been seen to provide any significant effects on the biodiversity and conservation in Peninsular Malaysia.

\section{Illegal Orchid Collection and Smuggling in Malaysia}

In the past few years, over collecting has become an increasing problem. Due to orchid flowers' fragrant, colour, size, shape and high market demand, either commercial collectors or researchers tend to do over collection. Some of the more spectacular orchid species also being sold at the roadside (common between Tapah and Cameron Highlands), at night and Sunday market for a large profit. Those orchids that have been smuggle out from the protected area or 
jungles include the genus Paphiopedilum (the lady's slipper orchid), Phalaenopsis, Dendrobium, Coelogyne, Gramatophyllum (the tiger's orchid) and some Vanda species. Some of the foreign researchers and tourists have been caught for trying to smuggle some of the precious wild orchids from Malaysia to another country. These Orchids are said have high commercial values, for example, RM3000 - RM10,000 per port of Slipper Orchids and RM 5000 per port of Jewel Orchids (pers. comm. with orchid nursery owners). These challenging threats do deplete the number of wild orchid species in nature. Today, with ecommerce era, selling orchid species are becoming rampant and without checked. Prices of many rare, endemic and flagship species were drastically dwindling to mere USD 15.00 per pot of Jewel Orchids (eBay accessed 15 Dec. 2018), Dossinia marmorata (Borneo endemic jewel orchids) was priced at USD 25.00 per pot (www.blackjungleterrariumsupply.com), and many more are being traded for like non-protected plants. Though there is a very strict law governing the trade of endangered species (CITES and TRAFFIC) but enforcement is inadequate and inefficient specially to curb online trading.

\section{PART TWO}

\section{Consequences of Clear felling Forest Degradation Towards Orchid Community in Malaysia}

\section{Consequences towards the Forests and Its Surrounding Ecosystem}

The logging activities have brought damages to the forest's soil and vegetation as its protective layer being swept away by the logging trucks and heavy machinery (Figure 1). The soil surface erosion and clearance in the logging sites have removed the tree canopies and leaf litters which then alter the $\mathrm{pH}$ and humidity, and then eventually eroded the nutrients from the soil. The full sunlight radiations heated up the ground in the logged forest without canopy protections have distorted the atmosphere and soil microclimatic stratifications, largely the nutrient content (Werner and Gradstein, 2009; Benítez et al., 2015). Following the heavy rains occurred in Kelantan since 2014, which had been seen as one of the major causes of floods in Kelantan but logging was said to worsen the situation. The absence of trees has charged a significant role in this situation. Naturally, part of the amount of rain would be intercepted by the leaves and other parts of the plant, then would be evaporated into the atmosphere. The amount of water that is not intercepted by plants would fall to the ground and so does the trunk of the tree. Without trees, unblocked rain water flows to the river and the river gets tense, and it erodes the banks of the river, even before that, the rainwater falling on the surface of the exposed soil also causes soil erosions. The mud floods are floods that result when strong rains on hill or mountain slopes caused by the extensive soil erosion. Conclusively, the mud floods were largely due to the absence of a buffering tree. As a result, the rainwater brought the mud and soil to a flat area, the lowland area. 


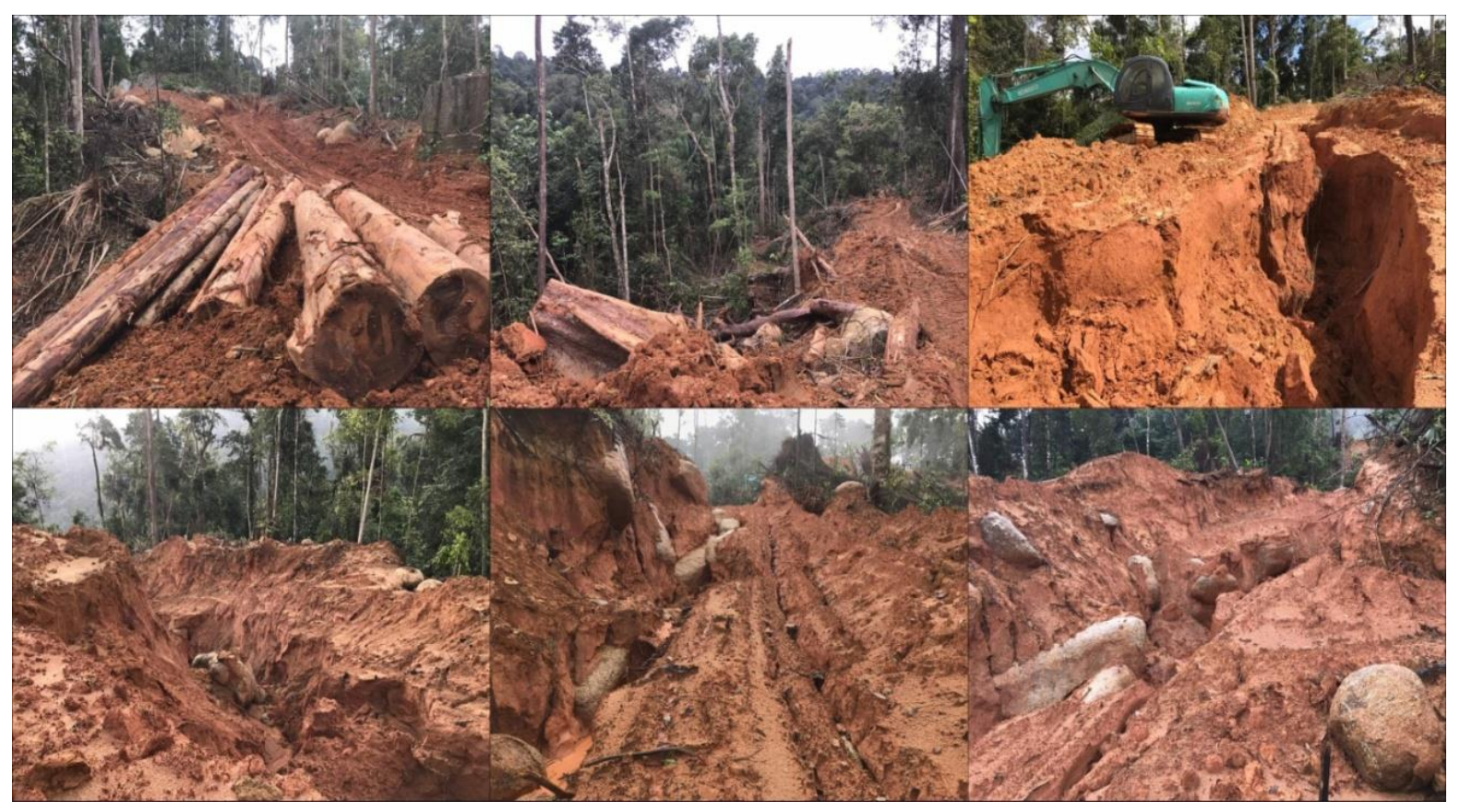

Figure 1: Severe conditions in the logging sites with open canopies, soil erosion and disturbed ground vegetation in Malaysia. These forest areas have been cleared and disturbed for more than three years, based on the surveys and empirical studies carried since November 2016. Photos by DigitalDome.

\section{Consequences towards Orchids Survivability and Diversity}

The removal of trees has reduced the space for colonization for the epiphytic plants, including the orchids. The canopy disruptions caused by clear cut forest logging and the mud flood events have changed the orchid's habitat and ecosystem (Figure 2). The anthropogenic-driven disturbances have significantly altered the humidity and temperature levels of the areas, which are the influential ecological factors behind the orchid survivability, including the pollination, flowering and seeds production leading their continual diversification. Nutrients accumulate in the soils delivered by rain, or accumulate through the activity of soil microorganism (Li et al., 2014). The nutrient accumulation also could be formed through decomposition of rocks and minerals, and from the atmosphere. The impact of timber harvest becomes apparent when the soil erosions and landslides occurrence reduced the soil capacity, which then eventually erode away the nutrient layer (Wan Mohd Shukri et al., 2007). Based on the current study, the disturbance-induced drought stress had also damaged the orchid morphological and interfered with their phenology occurrence. Even if there were still fragments of the original habitat available for their colonization, the gene flow and presence of pollinators were notably reduced, as observed. It was also observed that most the orchids in disturbed forests survived the long hot and dry conditions by distinctively possessed the divergent adaptive strategies. These adaptations might allow them to survive the long warm and dry conditions but it would not help them to survive longer in these harsh environments with intense heat and water-deficit. A single tall tree in the inland forest could harbour up to hundreds of orchid plants. This means that the large scale forest cutting and complete vegetative destruction could have affected a high abundance and diversity of the precious orchid species and destroyed them in a short time. 


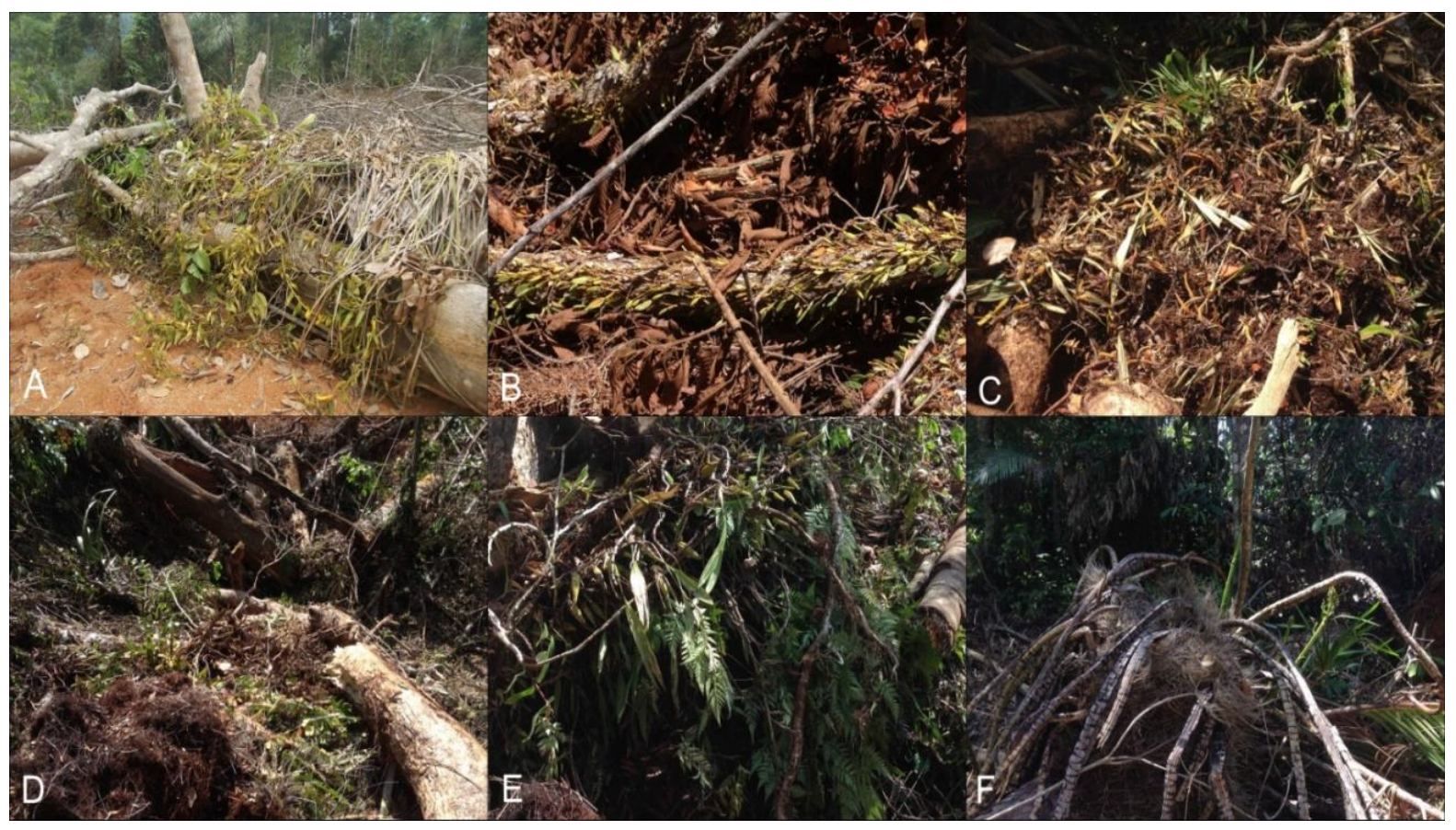

Figure 2: Clumps of 'dying' epiphytic orchids found on remnant tree trunks and ground in the logging sites in Malaysia; A: Cleisostoma, B: Dendrobium, C: Coelogyne and Bulbophyllum, D and E: Coelogyne, F: Grammatophyllum. Photos (B-F) by DigitalDome.

\section{Overview on Orchids Conservation Status in Malaysia}

Conservation of biodiversity in Malaysia has been a hot topic since the Earth Summit, Rio de Jeneiro, 1992. Many legislation and law has been developed nationally and internationally for protection of biodiversity, and are adopted fully in Malaysia. For example in Sarawak the Wild Life Protection Ordinance 1998 has all Paphiopedilum species, Phalaenopsis species, Arachnis species., Dossinia marmorata, Ludisia discolor, Calanthe hispada and Calanthe keratrifolia listed as Totally Protected Plants, where it states "no one may collect, cultivate, cut, trim, remove, burn, poison, in any way injure, sell, offer for sale, import, export, or be in possession of any Protected Plant or any part thereof except in accordance with a license issued by the Sarawak Forestry Department".

Federal agencies involve the administration of international treaties such as (i) Convention on International Trade in Endangered Species of Wild Fauna and Flora (CITES). It was established in 1973 and enters into force on 1 July 1975, controlling the international wild-collected orchid trading, to minimize the extinction of wild orchids from nature. CITES has the whole Orchidaceae family in its Appendices. All of the species that are listed in Appendix I are not permitted to be traded for commercial purposes. But the rules are dynamic and very much depends on the status of a species in the country. When careful measures have been taken in protecting a species from extinction or endangered, a species can eventually be down listed or even deleted from the Appendices. Seven species (Cattleya trianaei, Dendrobium cruentum, Laelia jongheana, Laelia lobata, Peristeria elata, Renanthera imschootiana and Vanda coerulea) and two genera (Paphiopedilum and Phragmipedium) are listed as Appendix I species. However, CITES permits trade in species, which are less endangered but could become threatened if trade is not controlled and those species are included in Appendix II. As of December 2018, 183 nations are parties to CITES and Malaysia joined as party country on $20^{\text {th }}$ October 1977 (Cites.org); (ii) Convention on Biological 
Diversity (CBD). It was adopted at the United Nation Conference on Environment and Development in Rio de Janeiro, June 1992. The Convention is mainly focused on sustainable natural resources by urging the participating countries to identify their biodiversity. In situ and ex situ conservation is very much emphasized as well. Overall, it is meant to fill the gaps between existing laws dealing with the use of natural resources and provide a foundation for future national as well as international measures (Hagsater \& Dumont, 1996) and (iii) The World Conservation Union (IUCN). In the effort of conserving and sustaining the utilization of orchid species and their habitat, the Species Survival Commission (SSC) set-up the Orchid Specialist Group (OSG) in 1984, of which I have been a country representative since 2001, and it is supported by professional and non-professional volunteers worldwide. IUCN SSC-OSG became the principal sources of guidance on conservation knowledge, policy and technical advice and are implementers of the orchid conservation program (IUCN, 2018).

The 1997 IUCN Red List of Threatened Plants recorded 1779 threatened orchid taxa, included 22 Malaysian orchids, where six are critically endangered, nine endangered, four vulnerable and three not threatened (IUCN, 1997). However, many of the Malaysian species were not included to the list, due to insufficient information. The latest IUCN Red List published online on the $7^{\text {th }}$ November 2018 has listed 1307 species, 25 subspecies and 2 amazing species. The number decreased because many species were reassessed downgraded to not threaten category anymore.

Knowledge on conservation status has evolved in the field of Orchidology in the last ten years. There are a few publications that could pilot orchid conservation assessment in Peninsular Malaysia. The latest preliminary study of on conservation assessment of 86 of the 949 orchid species recorded in Peninsular Malaysia (9\% of the Peninsular Malaysia's orchid flora) was carried by FRIM in 2013 following the IUCN Red List Categories and Criteria version 3.1. Twenty-nine species were assessed as threatened with 10 species are Critically Endangered (CR) which are Cleisostoma, Corybas, Dipodium, Paphiopedilum, and including species from subfamily Apostasioideae. Also, 44 species fall within the Data Deficient (DD) category, which they are known, had been collected about 60 to 100 years ago. Some of them were collected from severely degraded areas. On specific type of vegetation, Go et al. (2009) has concluded at least 15 species endemic to limestone has become rare in the wild in Perlis, Bau and Padawan Sarawak which mainly attribute to lack of knowledge, involvement among researchers and lack of awareness among local communities on the importance of utilizing their natural resources in a sustainable manner. In addition, a conservation status assessment of orchids of highland forest in Peninsular Malaysia revealed that 47 orchid taxa from Gunung Ulu Kali, Genting Highland were threatened with extinction ( $\mathrm{Ng}$, et al., 2012), including Corybas, in which, conclusively, judging from the small number of recollections, the small population sizes and degraded habitats where they grow, Corybas species in Peninsular Malaysia are all threatened by extinction in the wild (Go et al., 2015).

\section{PART THREE}

\section{Recommendations for Improvement of Legislations on Forests and Lands Management in Malaysia}

Revisions on the available acts related to forest protection in Malaysia, including National Forestry Policy 1978 (NFP) and National Forestry Act 1984 (NFA) have been done since early 1900s to include the conservation of biodiversity, the sustainable utilisation of forest genetic 
resources, more stringent penalties for rule violations, and the role of local communities in forest development and safeguarding. To ensure a successful implementation, state authorities have been formulating and enforcing more acts and laws, including the adoption of the National Timber Industry Policy (NATIP) 2009-2020. Prior to the protection against international trade, the Parliament has approved Malaysia's International Trade in Endangered Species Act 2008 and then implemented CITES to legislate the administration of international trade in wild fauna and flora in the country, so that any actions applied does not threaten the survival of the species. The penalty enforcement requires a high power of authority and have been assigned as a part of the Forestry Department's tasks.

There are many unreported but seen forest destruction events within the National Park area which has converted the fragments of the virgin forest to secondary habitat. There are different perceptions on the logging activity within the Malaysia region. Some parties implied based on their surveys involved some officers to the scene found no illegal logging, but rather ordinary by just logging in a controlled condition were being set. The logging methods applied were said to be not affecting the forest biodiversity, but instead the trees are planted to be revived again after 30 years, and permits to cut trees are only given by the quota allowed including the size of the timber that can be harvested. However, extreme changes in the local climates proves otherwise, which have been experienced in the past few years where the temperature and heat have fluctuated to a dangerous level and the reduced number of rainy days have been observed mainly caused by the absence of buffering trees. Therefore, a few recommendations are outlined in this report for future improvement in the implementation and strengthening the value of the conservation attempts.

First is to involve serious participations from the devoted conservation biologist in any legal logging or timber extraction activities in the permanent forest reserve by starting the conservation action or rescue mission, including the diversity study in the area being affected before the logging are started. Second is to evaluate the selected sites prior to the selection of 'preserved' sites based on eight criteria outlines by Given (1994) and Schuiteman \& de Vogel (2000). These criteria include the (i) diversity, (ii) conservation status assessment, (iii) new records, (iv) population size, (v) habitat specificity, (vi) size of the area, (vii) ecology study, and (viii) current and future threats facing by the orchids and their habitats. Also, deriving from the result obtained in the current study, a high accumulation of epiphytic orchids found on the fallen trees in the logging sites, the old and large trees should be protected as the carriers since these trees are not only crucial for those epiphytes, but also may serve seed dispersal to the nearby regenerating forests (Wolf, 2005; Adhikari et al., 2015). Third is to involve participations from the geologist to reduce the risks of landslide, soil erosion and water pollution. Fourth is to reduce the scale of logging more towards the lowland area in order to reduce the possibility of soil erosion and mud flood. Fifth is an immediate implementation of the restoration project after the logging is ended, including the plantations of native species which can be conserved in their natural habitats to encourage fast-growing forest (Adhikari et al., 2015) to help connecting existing patches and host trees for better dispersal, facilitating gene flow between populations, and increasing space for colonization especially for the epiphytic orchids (Barnes \& Lowell, 1999). Sixth is to involve participation of conservation biologist from different institutions and organisation on the restoration project to acquire more manpower, effective plan and also funding by targeting a successful forest restoration within less than 30 years.

\section{DNA Barcoding for Endangered Orchids in Malaysia}


The ability of DNA barcoding in taxonomy makes it a very useful tool in identification of plants. The approach for Malaysia has been genus-by-genus, and rare and endemic species due to the tremendous number of species present, and fund constrained. However, to date, 5 important genera namely Corybas (Tan, 2013); Dendrobium (Moudi, 2013); Bulbophyllum (Hosseini, 2011) and Paphiopedilum (Rajaram, 2019) has been successfully barcoded and deposited in the BOLD data systems with various GenBank Accession numbers totalling 136 to date. In our study, we tested the efficacy of the core and supplementary barcodes of plant DNA barcoding by single use and also in combination for Paphiopedilum in Peninsular Malaysia and thus suggest the ideal barcode for identification. The use of DNA barcoding has great potential especially in identification and taxonomy of plants to clearly elucidate the species and remove confusion on very closely related species. Using the matK barcode, accurate identification of species in Paphiopedilum can be ascertained and can act as a molecular tag while supporting the morphological data by works of earlier taxonomists (Rajaram et al., 2019).

\section{Application of IUCN Red List Criteria at Regional and National Levels}

This is a reasonable option, particularly for a region with a high number of endemics or threatened near-endemics, or when there currently is a pronounced overall deficiency of data pertaining to species' status within the region (IUCN, 2012), such in Peninsular Malaysia. The regional proposed conservation status of each orchid species is evaluated according to the guidelines for application of IUCN Red List Criteria at Regional and National Levels version 4.0 (prepared by the IUCN Species Survival Commission and revised by the National Red List Working Group of the IUCN/SSC Red List Committee in January 2010).

\section{Malaysia Biodiversity Information System (MyBIS)}

MyBIS is to be a one-stop repository for biodiversity information in Malaysia. MyBIS provides the information exchange platform of the CBD. The missions are; (i) to collate information related to Malaysia's biodiversity from a variety of sources, (ii) to provide easy access to and make available for public circulation, information, databases and other relevant material, provided by various stakeholders, (iii) to create public awareness on biodiversity and environmental issues, and (iv) to provide updated statistical analysis on biodiversity data. Data providers for this system are various agencies. Biodiversity information deposited in this website are abstracted from published books, journals, expert checklists and specimen databases.

\section{Conservation Strategy through Publication of Books on Wild Orchids in Various Habitat Types in Malaysia}

The production of these books timely and an important initiative coinciding with the effort of the Malaysian Government for safeguarding its biological diversity by managing its sustainable use in such a way that as many people as possible can benefit from it today and in the future. This book offers species easy-to-read descriptions including their photographs, scientific names, localities, and distinctive features to showcase the beauty our rainforests ecosystem has to offer, with the hope of enhancing public awareness on the importance of conserving the endangered species and Malaysia's tropical rainforest biodiversity especially for our grandeur orchids. To date the first author has steered authored 14 books, 9 specifically on wild orchids of Malaysia (Table 1). These publications are fruits of the team's labour of hard work 
botanising many inaccessible forests in Malaysia. Nevertheless, these books are not a renewal of our conservation vows; it has long been there, neither should it be a mere pallid compromise nor should it be left as a decorated item. Hence, it is the authors' hope that these publications be the resources of knowledge on orchids for the present and future generation, instilling passion for these beautiful jewels and inspiring everyone to support the wild orchids conservation efforts in Malaysia. The followings are the books authored and published so far or soon to be published by Go et al. (Table 1).

Table 1: List of books on Wild Orchids and other Plants of Malaysia (Peninsular Malaysia and Sarawak) (Figure 3)

\begin{tabular}{|c|c|c|c|c|}
\hline No & Title & $\begin{array}{c}\text { Year of } \\
\text { Publication }\end{array}$ & $\begin{array}{c}\text { Habitat/Forest } \\
\text { Types }\end{array}$ & State \\
\hline 1. & Orchids of Perlis: Jewels of the Forest & 2004 & Limestone & Perlis \\
\hline 2. & $\begin{array}{l}\text { Orchids of Peat Swamp Forest in } \\
\text { Peninsular Malaysia }\end{array}$ & 2008 & Peat Swamp & Selangor \\
\hline 3. & $\begin{array}{l}\text { Orchids of Perlis: Jewels of the Forest } \\
\text { (Revised Edition) }\end{array}$ & 2010 & Limestone & Perlis \\
\hline 4. & $\begin{array}{l}\text { Paya Indah Wetlands: The Array of } \\
\text { Plant Life }\end{array}$ & 2013 & Wetland & Selangor \\
\hline 5. & $\begin{array}{l}\text { Orchidea Selangoreana (Wild orchids } \\
\text { of Selangor) }\end{array}$ & 2014 & $\begin{array}{l}\text { Lowland to } \\
\text { Montane }\end{array}$ & Selangor \\
\hline 6. & $\begin{array}{l}\text { Orchids of the Montane Forests of } \\
\text { Peninsular Malaysia }\end{array}$ & 2015 & Montane & $\begin{array}{c}\text { Throughout } \\
\text { Peninsular } \\
\text { Malaysia }\end{array}$ \\
\hline 7. & $\begin{array}{l}\text { Discovering the Wonders of Malaysia } \\
\text { Orchids: Unveiling Vanilla } \\
\text { norashikiniana }\end{array}$ & 2017 & $\begin{array}{l}\text { Lowland to } \\
\text { Hill }\end{array}$ & $\begin{array}{l}\text { Throughout } \\
\text { Peninsular } \\
\text { Malaysia }\end{array}$ \\
\hline 8. & Sarawak Limestone Forests Orchids & 2018 & Limestone & Sarawak \\
\hline 9. & $\begin{array}{l}\text { Enchanted Orchids of Fraser's Hill: A } \\
\text { Pictorial Guide }\end{array}$ & 2019 & Montane & $\begin{array}{l}\text { Pahang \& } \\
\text { Selangor }\end{array}$ \\
\hline 10. & Ethnobotanical Plants of Malaysia & 2019 & All Habitats & $\begin{array}{l}\text { Peninsular } \\
\text { Malaysia }\end{array}$ \\
\hline 11. & $\begin{array}{l}\text { Wild Orchids of Terengganu: The } \\
\text { Vanishing Jewels }\end{array}$ & 2020 & $\begin{array}{l}\text { Disturbed } \\
\text { Forests }\end{array}$ & Terengganu \\
\hline 12. & Notable Plants of Malaysia & 2020 & All Habitats & $\begin{array}{l}\text { Peninsular } \\
\text { Malaysia }\end{array}$ \\
\hline 13. & $\begin{array}{l}\text { Magnificent Wild Flowers of Fraser's Hill } \\
\text { Selangor State Park }\end{array}$ & 2020 & $\begin{array}{l}\text { Hill and } \\
\text { Montane Forests }\end{array}$ & Selangor \\
\hline 14. & $\begin{array}{l}\text { Shah Alam Orchid City: Inauguration of } \\
\text { the Selangor Royal's Orchids }\end{array}$ & 2020 & $\begin{array}{c}\text { Urban } \\
\text { Landscape }\end{array}$ & Selangor \\
\hline
\end{tabular}




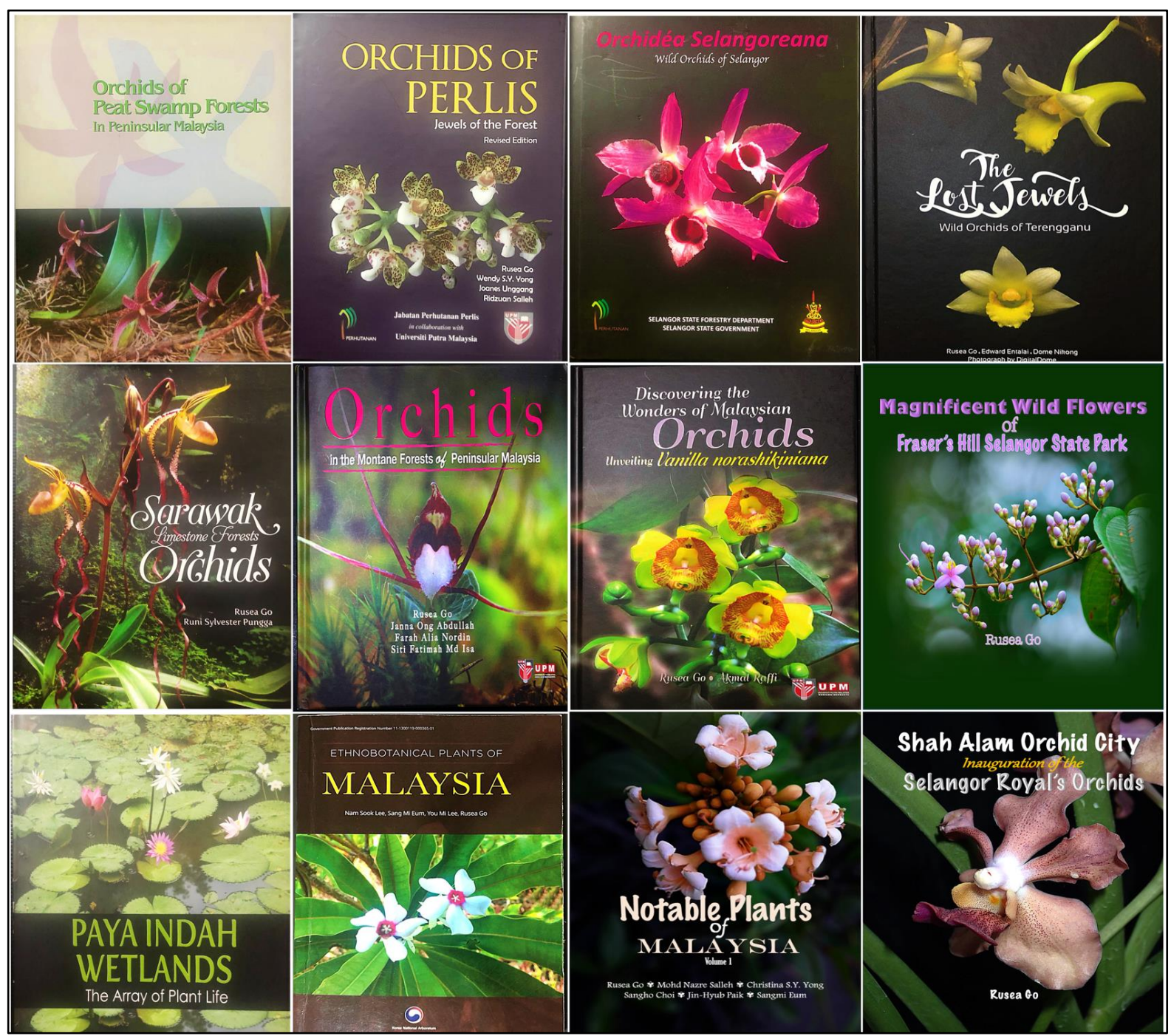

Figure 3: Books on Wild Orchids of Malaysia authored by Go et al. since 2004.

\section{CONCLUSION}

The world of wild orchids in tropical rainforests has always fascinates people who loves nature, and their discovery is a never-ending journey. In 22 years of discovering, enjoying their beauty and loving them is worthless if none of this knowledge documented and disseminated to the public for the benefit of mankind. All states in Malaysia has their respective forest reserves situated in the Totally Protected Areas (TPA), and have most of their orchids conserved in situ, while others found in the production forests and community forests are prone to disturbances that pose a continued threat to orchid's population, thus ex situ conservation is the best option. All State Government are committed in ensuring sustainable protection of her biodiversity, including orchids, which is apparent in various legislations and pledges made at national as well as international arenas, and the impressive expanse of totally protected forests. The study, documentation and publication of orchid flora books is an excellent example of successful collaborative effort between UPM and the various state government in promoting productive research and creating awareness towards orchid conservation. It is generally conceded that there is lacking of information concerning the current conservation status of orchids such as the endangered, rare or endemic species, and these have contributed to the difficulty of planning a strategy for its' conservation and protection, plus the lack of expertise and 
willingness to do the much needed evaluation. The increasing global interest in wild orchids, particularly its trade has resulting increase for orchid pouching among collectors that have critically stripped the species from the forests to the extent it has caused the species to become rare in the wild and is now threatened with extinction. Hence, study of Malaysian wild orchids should continue to compliment the effort of the Malaysian Government for safeguarding its biological diversity by managing its sustainable use in such a way that as many people as possible can benefit from it today and in the future.

\section{Acknowledgement:}

Firstly, our gratefulness is extended to the Forest Department Peninsular Malaysia [Reference No.: JH/100 Jld. 16(14)] and Department of Wildlife and National Parks Peninsular Malaysia [Reference No.: JPHL\&TN (IP): 100-6/1/14(6)] for granting us the permits to access the studied areas. We would like to thank the UPM-KRIBB (Korea Research Institute of Bioscience and Biotechnology) Vot. 6384300 and UPM for the research funding (Putra Grant No. 9413603). We owe sincere thanks to many experts for their consultations and opinion. We are also very thankful to the staffs and friends who directly or indirectly contributed to the success of this study. The authors contributed equally to this paper, and approved the paper for release and agree with its content.

\section{Author Contributions:}

Conceptualization, Rusea Go; Data curation, Rusea Go, Edward Entalai BESI, Mohd Puat DAHALAN, Raffae AHMAD, Ag. Shaffie AG. AHMADNI and Runi SYLVESTER PUNGGA; Formal analysis, Rusea Go and Edward Entalai BESI; Funding acquisition, Rusea Go, Raffae AHMAD, Ag. Shaffie AG. AHMADNI and Runi SYLVESTER PUNGGA; Investigation, Rusea Go, Edward Entalai BESI, Mohd Puat DAHALAN and Runi SYLVESTER PUNGGA; Methodology, Rusea Go; Project administration, Rusea Go, Ag. Shaffie AG. AHMADNI and Runi SYLVESTER PUNGGA; Resources, Rusea Go, Mohd Puat DAHALAN, Raffae AHMAD, Ag. Shaffie AG. AHMADNI and Runi SYLVESTER PUNGGA; Supervision, Rusea Go, Raffae AHMAD, Ag. Shaffie AG. AHMADNI and Runi SYLVESTER PUNGGA; Validation, Rusea Go, Mohd Puat DAHALAN and Runi SYLVESTER PUNGGA; Visualization, Rusea Go; Writing - original draft, Rusea Go and Edward Entalai BESI; Writing - review \& editing, Rusea Go, Edward Entalai BESI, Mohd

Conflicts of Interest: We declare that we do not have conflict of interest in this publication and all co-authors agreed for publication of this paper.

\section{References}

Abdul Rahman, A.R. (2012). 'The State of Our Forest in Peninsular Malaysia'. In: The public awareness campaign on forest conservation in Malaysia. Sunway Pyramid Shopping Centre, Selangor, Malaysia.

Adhikari, Y.P., Fischer, A. \& Pauleit, S. (2015). Sustainable conservation perspectives for epiphytic orchids in the Central Himalayas, Nepal. Applied Ecology and Environmental Research, 13(3), 753-767.

Akademi Sains Malaysia (2014). Mega Science 2.0 (Sectorial Report: Environment). Academy of Sciences Malaysia, Kuala Lumpur, Malaysia, 147 pp. 
American Orchid Society (AOS), (1983). Retrieved from http://www.aos.org/aboutus/orchids-magazine.aspx, accessed on August 1, 2017

Barnes, T.G. \& Lowell, A. (1999). A Guide to Urban Habitat Conservation Planning. University of Kentucky Cooperative Extension Service. Retrieved from http://www.ca.uky.edu, accessed on March 9, 2017, Issued 5-99.

Benítez, Á., Prieto, M. \& Aragón, G. (2015). Large trees and dense canopies: key factors for maintaining high epiphytic diversity on trunk bases (bryophytes and lichens) in tropical montane forests. Forestry: An International Journal of Forest Research, 88(5), 521-527.

BERNAMA (2015, March 5). Logging Still Rampant in Gua Musang. Retrieved from http://www.bernama.com/en/features/news.php?id=1113908, accessed on August 1, 2017.

Chase, M.W. \& Fay, M.F. (2009). Barcoding of plants and fungi. Science, 325(5941), 682683. https://doi.org/10.1126/science.1176906

Davis, S.D., Droop, S.J.M., Gregerson, P., Henson, L., Leon, C.J., Villa-Lobos, J.L., Synge, H. \& Zantovska, J. (1986). Plants in Danger: What Do We Know? IUCN Conservation Monitoring Centre, Royal Botanic Gardens, Kew, United Kingdom.

Given, D.R. (1994). Principles and Practice of Plant Conservation. Oregon, U.S.A: Timber Press, Inc., 292 pp.

Go, R, \& Hamzah, K.A. (2008). Orchids of peat swamp forests in Peninsular Malaysia. Forest Research Institute Malaysia (FRIM), Kepong, Malaysia, Peat Swamp Forest Technical Series No. 13, 136 pp.

Go, R. \& Pungga, R.S. (2018). Sarawak Limestone Forest Orchids. Sarawak Forest Department, Kuching, Malaysia, 200pp.

Go, R. \& Raffi, A. (2017). Discovering the Wonders of Malaysian Orchids: Unveiling Vanilla norashikiniana. UPM Press, Serdang, Malaysia, 98 pp.

Go, R., Dahalan, M.P. \& Abdul Manaf, M.B. (2014). Orchidèa Selangoreana (Wild Orchids of Selangor). Selangor State Forestry Department, Selangor, Malaysia, in association with Selangor State Department, Selangor, Malaysia, 207 pp.

Go, R., Hj. Abdul Ghani, P., Norain, M., Azroie, M.M.Y. \& Khor, H.E. (2013). Paya Indah Wetlands: The Array of Plant Life. Ministry of Natural Resources and Environment, Kuala Lumpur, Malaysia, $100 \mathrm{pp}$.

Go, R., Lim, M.Y.L., Phoon, S.N., Yong, W.Y.S., Tang, C.H., Khor, H.E., Janna, O.A. \& Abdullah, J. (2009). Malaysian limestone orchids status: diversity, threat and conservation. Blumea, 54(1-2), 109-116.

Go, R., Nordin, F.A. \& Dahalan, M.P. (2019). Enchanted Orchids of Fraser Hill: A Pictorial Guide. Forestry Department of Selangor and Selangor State Government, Kuala Lumpur, Malaysia, $120 \mathrm{pp}$.

Go, R., Tan, M.C., Naruddin, A.A., Abdullah, J.O., Ng, Y.J., Nordin, F.A., Khor, H.E. \& Nulit, R. (2015). Extinction risks and conservation status of Corybas (Orchidaceae; Orchidoideae; Diurideae) in Peninsular Malaysia. Phytotaxa. 233(3), 273-280.

Go, R., Yong, W.S.Y., Unggang, J. \& Ridzuan, S. (2010). Orchids of Perlis, jewels of the forest (Revised Edition). Jabatan Perhutanan Perlis, Perlis, Malaysia, in association with Universiti Putra Malaysia, Serdang, Malaysia, $152 \mathrm{pp}$.

Hágsater, E. \& Dumont, V. (1996). Conservation threats. Orchids: status, survey, and conservation action plan. IUCN, Gland, 6-9.

Hairul, N.M.K, Ramle, A., Mohamad, H.A.S. \& Asmawi, I. (2016). Kelestarian alam sekitar taman negara Tasik Kenyir dan impak kesejahteraan kepada masyarakat orang asli sekitar. International Conference on Education and Regional Development 2016 (ICERD 2016). [Note: Article published in Malay language] 
Hosseini, S. (2011) Molecular Systematic of the Genus Bulbophyllum in Peninsular Malaysia. Master of Science Thesis. Universiti Putra Malaysia, Selangor, Malaysia.

IUCN (1997). The IUCN Red List of Threatened Species. Retrieved from http://www.iucnredlist.org, accessed on December 15, 2018.

IUCN (2018). The IUCN Red List of Threatened Species. Retrieved from http://www.iucnredlist.org, accessed on December 15, 2018.

IUCN/SSC Orchid Specialist Group (1996). Orchids-Status Survey and Conservation Action Plan. IUCN, Gland Switzerland and Cambridge, United Kingdom.

Kiew, R. (1991). The limestone flora. In: Kiew, R. (ed.). The State of Nature Conservation in Malaysia. Malayan Nature Society, Kuala Lumpur, Malaysia, pp 42-50.

Li, X., Niu, J. \& Xie, B. (2014). The Effect of Leaf Litter Cover on Surface Runoff and Soil Erosion in Northern China. PLoS ONE, 9(9), e107789.

Lye, T.P. (2000). Forest, Bateks, and Degradation. Japanese Journal of Southeast Asian Studies, 38(2), 165-184.

Lye, T.P. (2005). Changing pathways: forest degradation and the Batek of Pahang. Strategy Information Research Development, Petaling Jaya, Selangor, Malaysia, $227 \mathrm{pp}$.

Moudi, M., Yien, C.Y.S., Nazre, M., Janna, O.A. \& Go, R. (2013). Phylogenetic Analysis Among Four Sections of Genus Dendrobium Sw. (Orchidaceae) in Peninsular Malaysia using rbcL Sequence Data. International Journal of Bioassays, 02(06), 932-937.

National Forestry Act 1984. Retrieved from https://www.forestry.gov.my/index.php/en/aktaperhutanan-negara-1984, accessed on January 12, 2018.

National Forestry Policy $1978 . \quad$ Retrieved from https://www.forestry.gov.my/index.php/en/about-us/national-forestry-policy, accessed on January 12, 2018.

National Timber Industry Policy 2009-2020. Retrieved from http://www.mtib.gov.my/natip/Natip3.pdf, accessed on January 12, 2018.

Rajaram, M.C., (2019). DNA Barcoding of Endangered Paphiopedilum of Peninsular Malaysia (Slipper Orchid). (Master of Science thesis). Universiti Putra Malaysia, Selangor, Malaysia.

Rajaram, M.C., Christina S.Y., Yong, \& Rusea Go. (2018). DNA Barcoding of Endangered Paphiopedilum species (Orchidaceae) of Peninsular Malaysia. Phytotaxa 387(2), 094104.

Schuiteman, A. \& de Vogel, E.F. (2000). Orchid Genera Thailand, Laos, Cambodia and Vietnam. The Netherlands: National Herbarium Nederland, 188 pp.

Selvaraj, D., Shanmughanandhan, D., Sarma, R.K., Joseph, J.C., Srinivasan, R.V., \& Ramalingam, S. (2012) DNA barcode iTS effectively distinguishes the medicinal plant Boerhavia diffusa from its adulterants. Genomics, Proteomics \& Bioinformatics 10(6), 364-367.

SINAR (2017, September 18). Pembalakan punca banjir lumpur. Retrieved from http://www.sinarharian.com.my/, accessed on March 3, 2018.

Sønstebø, J.H., Gielly, L., Brysting, A.K., Elven, R., Edwards, M., Haile, J., Willerslev, E., Coissac, E., Rioux, D., Sannier, J. \& Taberlet, P. (2010). Using next-generation sequencing for molecular reconstruction of past Arctic vegetation and climate. Molecular Ecology Resources, 10(6), 1009-1018.

Tan, M.C. (2013). DNA Barcoding for Rare and Endangered Corybas Species in Peninsular Malaysia. (Master Dissertation). Universiti Putra Malaysia, Selangor, Malaysia.

Techen, N., Parveen, I., Pan, Z. \& Khan, I.A. (2014) DNA barcoding of medicinal plant material for identification. Current opinion in Biotechnology, 25, 103-110.

Wan Mohd Shukri, W.A., Ismail, H., Nur Hajar, Z.S. \& Mohd Rizal, S. (2007). Logged-over forests under the selective management system: a case study in Jengai Forest Reserve, 
Terengganu. pp. 68-77. In: Nik Zanariah, N.M., Sarifah, K.A. \& Nor Azman, H. (eds). Highlight of FRIM'S IRPA Projects 2006. Forest Research Institute Malaysia, Kepong, Malaysia.

Werner, F.A. \& Gradstein, S.R. (2009). Diversity of dry forest epiphytes along a gradient of human disturbance in the tropical Andes. Journal of Vegetation Science, 20, 59-68.

Wolf, J.H.D. (2005). The response of epiphytes to anthropogenic disturbance of pine-oak forests in the highlands of Chiapas, Mexico. Forest Ecology and Management, 212, 376393.

Wong, S.L. (2002). Plant Life. In Pearl of Perlis: Perlis State Park Guide, eds. Osman K., R. Amat and S. Suksuwan. Forest Department of Perlis, Kangar, Perlis, Malaysia.

Yong, W.S.Y., Go, R., Tang, C.H., Abdullah, J.O. \& Osman, K. (2005). Orchids of Perlis: New Records and Distribution. Pertanika Journal of Tropical Agricultural Science, 28(2), 135-146. 